INTERNATIONAL DESIGN CONFERENCE - DESIGN 2018

https://doi.org/10.21278/idc.2018.0102

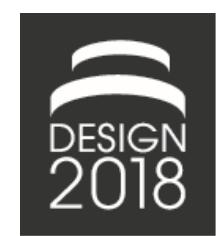

\title{
EVALUATION METHOD IN ENERGY EFFICIENT DESIGN OF COOLING PLANTS
}

\author{
K. Osman, Ž. Tomaš and D. Pervan
}

\begin{abstract}
The paper presents research in connection with a method of evaluating different cooling plant system architecture. This method is of analytical nature and is to be used primarily effectively solve problems regarding the selection of a cooling plant system architecture. A satisfactory solution here refers to a solution with a lower cost of total electricity consumption. The method's verification is presented by comparing two cooling plant with water cooled chillers system architecture. First of them is using cooling towers, while the other using dry coolers in the same mode.
\end{abstract}

Keywords: evaluation method, energy efficiency, complex systems, product architecture, cooling plants

\section{Introduction}

To maintain their competitive edge and operate successfully, as well as manage the constantly increasing global market demands, companies now need to respond very quickly, on a daily basis, to customer demands which are constantly changing and growing in the $21^{\text {st }}$ century (Justel et al., 2007). It may be said that their response to all such expectations plays a vital role in their business performance. Demands from customers and society in general significantly increase the growing demands for the quality, costs and time of delivering technical products (Hosnedl et al., 2010). In this context, the decision-making process is one of the most important factors in all that and it may be said that companies need to have an "optimal" response to the intended market dynamics. In the system architecture designing process, we very often see decisions to select the cheapest, sometimes the optimal alternative system solutions. In the overall decision-making process, evaluation of alternatives is a task very relevant to the designing process, which highly affects the outcome of decision-making, as well as the quality of the system (Zapaniotis and Dentsoras, 2011). It may be said that an effective analysis of a set of alternatives and searching for the best solution are an inseparable part of the design (Kroll and Weisbrod, 2015). To reach the target, it is sometimes necessary to take into account different priorities in selecting the best alternative, i.e. several different criteria. In designing processes, there is a strong need for ongoing evaluation of alternatives, which should be carried out using systematic, reliable and preferably problem-independent methods (Zapaniotis and Dentsoras, 2011).

Industrial cooling processes very often use plants featuring water cooled chillers/heat pumps, which are able to frequency-manage the cooling capacity range (in particular where there are several types of energy-consuming devices that do not require the same amount of cooling energy in all seasons) (Hanson et al., 2011). In such cases, the release of heat into the environment is managed by installing cooling towers, a dry cooler or a combination thereof. It all depends on the operating conditions and the time of year such plant is intended to be used in. As regards the initial investment, cooling plants using watercooled water chillers/heat pumps require quite substantial investments, including the costs of required 
energy, as well as the maintenance costs. On the other hand, their energy efficiency, usability and lifecycle levels are much higher (Energy Design Resources, 2010). This is why they are very interesting to study to people working in this area. The paper therefore considers and proposes a practical method of comparing (evaluating) such plants, where an energy analysis is intended to demonstrate the justifiability of using a particular concept by presenting how much energy is saves compared to other cooling plant concepts.

The example provided below, intended to present the evaluation method, makes a comparison of two cooling plant concepts with a water cooled chillers during the winter and transitional operating modes in a year. Regarding the efficiency of the system and its energy consumption, we compared two concepts - operation in the free cooling mode with cooling towers (Option 1) and operation in free cooling mode with dry coolers (Option 2).

The main design challenge in the writing of this paper was to systemically present one of the concept comparison methods quite often used by the authors in their work. The method itself is quite comprehensive and requires a substantial amount of time to find an acceptable solution. As many parameters used for the method were selected based on certain input assumptions and experience, quite a number of decisions were made relatively quickly, both as a result of the scope of necessary data and the experience of someone who has dealt with the method and all necessary data gathering and calculations it includes. The authors aimed to present their approach to solving these and other similar problems and perhaps thus help a practicing engineer who encounters similar problems.

The next section briefly addresses some earlier research by the authors which this research is an extension of, while Section 3 describes the authors' motivation for conducting this research. Section 4 provides a description of the method used and Section 5 presents its verification by comparing two cooling plant concepts in industrial cooling processes. The results obtained are discussed and addressed in Section 6. As the final section of the paper, Section 7 provides a conclusion for the research presented, as well as the possible directions of future research.

\section{Related work}

The research presented in this paper is an extension of research presented in papers by Osman, Pervan and Tomaš (Osman et al., 2016). This paper presents the methodology to be used to develop cooling plant architectures through 4 basic iterating steps, which means that several steps must be completed to obtain the intended cooling plant system architecture, and is based on equipment supplied by the manufacturer selected by the authors in the system designing phase, namely TRANE (C) (TRANE, 2001). It is important to note that it is also applicable to other equivalent equipment supplied by other manufacturers. The next paper associated with this research by Osman, Pervan and Tomaš (Osman et al., 2017) presents the relevant approach including its steps through the product (water chiller) configuration phase, as well as change phases where improvements may be made based on the system's efficiency, the noise levels considering the building for which the plant is being designed, and the cost to purchase. Of course, investor and engineering requirements may be changed and the designers may suggest to the investor items that may be more suitable in the system configuration phase. That paper aimed to present and explain in greater detail the approach to configuring one of the cooling plant (with air or water cooled chiller) system's subsystems and those changes may be made to its system architecture and that such changes may be evaluated to obtain a satisfactory solution.

We would also like to mention Ullman (2010), who specifies several evaluation methods relating to the conceptual phase of the designing process and distinguishes between two main categories. The first category comprises absolute methods, which means that each concept is compared against a set of designing requirements. In the second category, the methods are based on a relative comparison between concepts. In his book, Ullman very generically describes how concepts are created, including their generation, evaluation and the relevant decision-making (as an iterative process). All this is documented and discussed, and certain concepts are later detailed and then refined, approved or rejected.

A similar paper was provided by Duda (2012), which essentially presents the entire methodology of creating an efficient cooling plant, as presented in earlier papers by Osman, Pervan and Tomaš (Osman et al., 2016, 2017), except that Duda based their decisions on the Simple Payback Method (ASHRAE, 2011) and the Uniform Series Present Worth Factor (USPWF) to calculate the costs of the energy to be used in each year of the product's lifecycle. This paper uses a different approach - the price was calculated on the 
basis of the energy actually used for each day and each month analysed based on the average outside air temperature on the basis of data actually received for several years preceding the research year.

In general, efficiency may be said to indicate how input signals are used in the system. If the system is an efficient one, it is said to use its input signals correctly. If the system is an energy-efficient system (such as the cooling plant presented), the idea is to generate as much thermal capacity (cooling and heating energy) as possible to be delivered to consumers with as little (input) electricity used as possible. $100 \%$ energy efficiency could be achieved if the system were to always produce and generate maximum necessary and required energy over a planned period of time. However, this is not possible to completely achieve due to external impacts, malfunctioning equipment and the human factor. Of course, a concept which is the cheapest in terms of the energy used (public water and electricity) is also taken into account. Each manufacturer defines a useful life for their equipment. The ratio between cost and quality and the estimated useful life of the product (including both the necessary replacements of certain machine components and the eventual replacement of the machine itself after a certain number of years) are also always taken into consideration in this context. Sometimes, machine replacement is a result of new legislation which, for example, requires the use of new coolant (Freon) in machines. Determining the availability of the system can be said to be quite a stochastic process because we are never able to tell with a particular degree of certainty that a particular system will operate at a particular time and thus rule out any unforeseen events such as failure or malfunction.

The method presented in this paper is based on author's extensive experience in designing cooling plants in the Republic of Croatia for the food and pharmaceutical industry. As there are quite a few similar companies dealing with the matters in question in our market, we found it relevant to present the development of this evaluation method.

\section{Motivation}

Based on the relevant literature (Energy Design Resources, 2009) and engineering experience, there are three factors relevant to term of the efficient cooling plant. The first one is an efficient system concept. The selection an appropriate system concept represents a response to the expected operating conditions. Efficient system components are the second relevant factors. It is necessary to select components such as water chillers/heat pumps, fans and electric motors that also have maximum possible efficiency as autonomous systems. In addition to all this, their proper setting, commissioning and operation represent the third relevant factor. In case of major deficiencies in any of the three factors, they will be very difficult to overcome in any of the other two.

The main design challenge in the writing of this paper was to systemically present one of the concept comparison methods quite often used by the authors in their work. The method itself is quite comprehensive and requires a substantial amount of time to find an acceptable solution. As many parameters used for the method were selected based on certain input assumptions and experience, quite a number of decisions were made relatively quickly, both as a result of the scope of necessary data and the experience of someone who has dealt with the method and all necessary data gathering and calculations it includes.

This is why the authors are motivated to present through this paper a proposal for an analytical evaluation method that would very effectively solve the problem of selecting the first factor - the cooling plant system concept. Irrespective of its complexity, the authors believe it will be helpful both to inexperienced designers and to designers that have dealt with the matters in question for quite a few years. By further applying it to subsequent similar problems, a satisfactory solution for the system may be found very quickly. Based on the results obtained, it is later very easy to present one's preferences and, in particular, convince the investor to choose the proposed system concept option.

\section{Description of the evaluation method}

The evaluation method presented in this paper is a continuation of the research published in the Osman, Pervan and Tomaš (Osman et al., 2016, 2017) papers and an extension of the methodology to be used to develop cooling plant architectures, as described in the paper by Osman, Pervan and Tomaš (Osman et al., 2016). We will briefly address such methodology so that we could incorporate the method description therein. 
The methodology for the development of energy efficient system architectures (this specifically refers to cooling plants) consists of 4 basic steps. The methodology is able to make changes to system architectures, i.e. its feedback loop allows it to make changes both in customer requirements (i.e. in the engineering requirements defined on the basis of them) and changes in the selection of plant equipment. It has not yet been implemented for computer use and is being implemented partly by using analytical methods and partly by using software (system configurators) provided by the equipment manufacturer and used by the authors in the course of their work. It is important to note that it also applicable to software provided by other manufacturers of similar (equivalent) equipment.

The steps included in the methodology are as follows:

1. Define the customer (investor) requirements and engineering requirements;

2. Select each item of cooling plant equipment (Donjerković, 1996; Recknagel et al., 2012) - this includes several sub-steps:

a. selection of chillers/ heat pumps;

b. selection of cooling towers;

c. selection of dry coolers;

d. selection of circulation pumps on the condenser and evaporator sides of the cooling plant;

e. dimensioning of the pipeline; and

f. selection of armature, measuring and controlling equipment.

3. Evaluation analysis.

The previous paper (Osman et al., 2017) presents the Configuration and Change Management approach (Step 2) of the methodology is elaborated)). i.e. the selection of a chiller. This approach also aims to obtain an optimal solution for the system, i.e. the chiller that will provide maximum energy efficiency at the minimal noise level required under the industry rules depending on the type of the building and the location of building the cooling plant, with minimal installation dimensions and equipment weight, and a cost to purchase as low as possible.

The evaluation method is associated with Step 3) of the mentioned methodology and includes the following steps:

1. Gathering outside temperature data - For the analyzed months for the analysis location, for each day of each analyzed month and each hour of each analyzed day. Data for the Republic of Croatia may be obtained from the official Meteorological and Hydrological Service. To obtain more accurate results, it would be advisable to collect data for several years back (e.g. for up to 5 years) for the analyzed month intended to be analyzed;

2. Average monthly temperature calculation - The average outside temperature is calculated for each day of the analyzed month for a particular time interval, e.g. of 3 hours each (8 time intervals during the analyzed day) over several years;

3. Defining the analyzed cooling effect - Based on the operating mode the cooling plants are compared against (compressor cooling or free cooling mode) and the average outside temperature values for each interval during the analyzed day, the cooling effects that may be provided by cooling plant components in the analyzed system architectures (cooling towers, dry coolers. etc.) are defined. It should be noted that, depending on the outside temperature, especially if we analyzed low outside temperatures (free cooling mode), these components will operate under reduced load in case of water chillers and at lower rotational speeds in case of dry coolers/cooling towers;

4. Determining the average cooling effect of each system architecture - We determine the average cooling effect depending on the desired operating mode under analysis and for those intervals of a day when out system components are intended to operate for each system architecture analyzed;

5. Calculating electric power for each component of the analyzed system architecture - The total transmitted electric power is determined for each component of the analyzed system architecture (such as the cooling towers, dry coolers, circulator pumps on the evaporator and condenser sides of the plant);

6. Determining the average electric power for each component of the analyzed system architecture - The average electric power is determined for each analyzed time interval during which a 
particular plant operating mode was analyzed based on the electric power calculated ( in the preceding Step 5) for each system component;

7. Calculation of cooling water loss on the cooling towers (optional) - The losses of cooling water are determined for the cooling tower component for a particular time interval during the analyzed day;

8. Electricity consumption calculation - Each component's electricity consumption is determined according to a predefined duration of each interval and according to the estimated electrical power for each component of the analyzed system architecture (Step 5). The total electricity consumption is determined for each component for each day of the month and their sum determines the total electricity consumption for each analyzed month;

9. Cooling water consumption calculation (optional) - Again, the consumption of cooling water is determined according to a predefined duration of each interval and according to the estimated cooling water losses on the cooling towers (Step 7). Consumption levels are later also determined for each day of the month, as well as cooling water consumption for each analyzed month.

10. Total electricity price calculation - The total price of the electricity used is calculated according to the total consumption of electricity for each analyzed month (Step 8) and according to the defined unit cost of electricity.

11. Calculation of the total price of cooling water used (optional) - According to the total consumption of cooling water for each analyzed month (Step 9) and the defined unit cost of such cooling water used, we determined the total price of cooling water used.

12. Comparing the proposed system architectures - Based on the data concerning electricity consumption, the total price of the electricity used, tot total price of energy used (including electricity and the cooling water used), we compared the proposed system architectures both for each analyzed month in the relevant operating mode and in aggregate for all months in a year.

13. Selection of the most convent option of system architecture - The more cost-effective option with a lower price of energy was selected based on the results obtained. To better illustrate the comparison between options, the factor EER (Energy Efficiency Ratio) (Saheb et al., 2006) may be calculated for the analyzed system architecture options both for a single day in the analyzed month and as the average EER for the whole analyzed month.

The entire method is graphically presented in Figure 1 (in the form of flow chart) and the algorithm itself will be detailed through a case study in the next Chapter 5 .

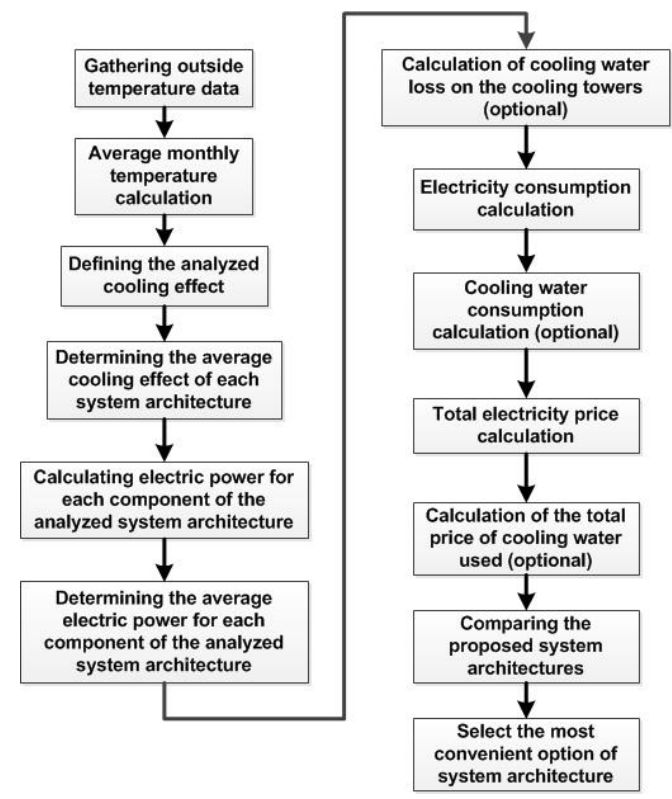

Figure 1. Evaluation method presented in the form of flow chart 


\section{Case study}

The evaluation method is based on an energy analysis of energy consumption (electricity and chemically treated cooling water) and is presented on the example of cooling plant in pharmaceutical industry on the north of Croatia (town Ludbreg), during the winter and transitional plant operating modes for the existing and new part of the cooling plant, conducted for the purpose of comparing the two options od system architecture proposed and presenting energy savings. This would demonstrate the justifiability of using/installing dry coolers in the existing part of the cooling plant, as well as part of the option for the new part of the cooling plant where they would be an integral part.

As can be seen in Figure 2 cooling plant have two main parts: condenser and evaporator side. On condenser side from the equipment we have cooling towers and condenser pumps, while on evaporator side we have evaporator circulation pumps and group of customers on the object. Chillers produce the required amount of cold water on evaporator side for customer needs, while on the condenser side through cooling towers they exchange waste heat with the environment.

It is planned that both parts of the plant (existing and the new one) will be connected, in case that one of them does not work, the other one will be supply both group of consumers on both parts (plant redundancy).

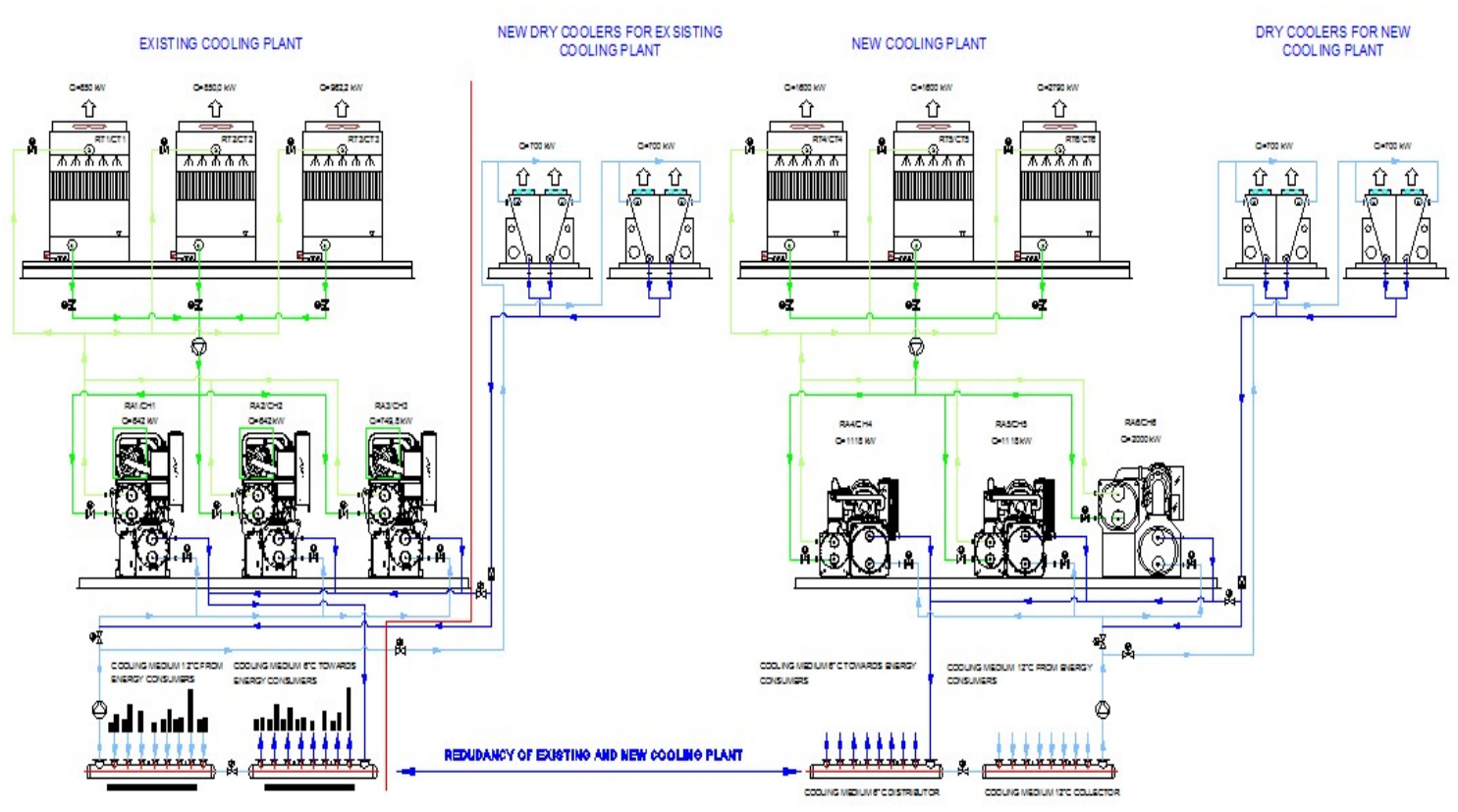

Figure 2. Schematic view of system architecture - option 1 and option 2

Based on data received from the official Meteorological and Hydrological Service in Republic of Croatia for outside temperatures in the October-March period and the values of average outside temperatures actually measures for the months on the building concerned, the following data was created.

Average temperatures were created for each analysed month (October, November, December, January, February and March), for each day and each hour, based on which the average temperatures for each hour in the analysed month were later obtained by analysis.

Presented below is one of the created diagram for month January intended to present the variations in the average outside temperature $\mathrm{T}_{\mathrm{v}, \mathrm{sr}, \mathrm{sat}}$ ) for each analysed hour (Figure 3 ).

We will use these created diagrams as reference values to assess the operation of the plant and they will help us create an algorithm for calculating energy consumption in the analysed parts of the cooling plant. 


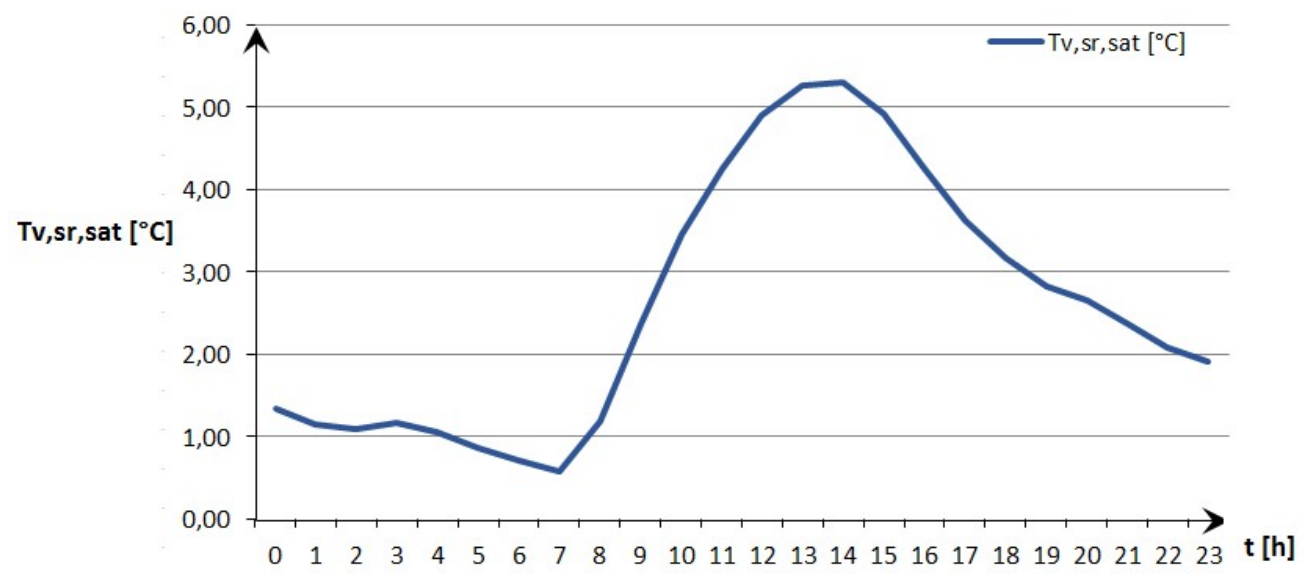

Figure 3. Diagram of ambient temperature variations for each analysed hour - month January

\subsection{Evaluation method for the existing part of the cooling plant}

For evaluation method purposes, we created an algorithm using software program Microsoft Excel, which allows us to calculate energy consumption and their cost (in the national currency of the Republic of Croatia Croatian Kuna identified as HRK) for the two options proposed.

The options proposed are as follows:

\subsubsection{System architecture - option 1 -operation with cooling towers in the free cooling mode}

The electricity consumption calculation (according to the average outside temperature for a particular time interval during a day in the analysed month), $\mathrm{E}_{\mathrm{el1}}[\mathrm{kWh}]$, is based on the following data:

- Total electric power transmitted to the cooling towers $\mathrm{N}_{\mathrm{T} 1}[\mathrm{~kW}]$ - provided by the equipment manufacturer;

- Total electric power transmitted to the condenser circulation pumps $\mathrm{N}_{\mathrm{pk} 1}[\mathrm{~kW}]$ - provided by the equipment manufacturer; and

- Total electric power transmitted to the evaporator circulation pumps $\mathrm{N}_{\mathrm{pi} 1}[\mathrm{~kW}]$ - provided also by the equipment manufacturer.

In addition, we calculated the cooling water consumption $\mathrm{V}_{\mathrm{rv} 1}\left[\mathrm{~m}^{3}\right]$ based on total losses of cooling water on the cooling towers $\Delta \mathrm{V}_{\mathrm{uk} 1}\left[\mathrm{~m}^{3} / \mathrm{h}\right]$ (including losses from evaporation and losses on tower nozzles provided by the equipment manufacturer).

Based on these two energy consumption values, we proceeded to calculate total energy consumption for the option proposed.

The prices of electricity for a particular interval were calculated by multiplying the known unit price of electricity $\mathrm{C}_{\mathrm{e} 22}[\mathrm{HRK} / \mathrm{kWh}$ (provided by an authorized electricity distributor for the town of Ludbreg) by total electricity consumption.

We also calculated the total price of the cooling water used $\mathrm{C}_{\mathrm{rv} \text {, uk1 }}[\mathrm{HRK}]$ by multiplying the unit price of cooling water used $\mathrm{C}_{\mathrm{rv} 1}\left[\mathrm{HRK} / \mathrm{m}^{3}\right]$ by cooling water consumption.

The total price of the energy used $\mathrm{C}_{\mathrm{uk} 1}[\mathrm{HRK}]$ was calculated as a sum of the total price of cooling water used and the total price of the electricity used $\mathrm{C}_{\mathrm{el} \text {, uk1 }}$ [HRK].

We also calculated the average coefficient EER $_{\text {post1 }}$ for all days, as well as the average value of such coefficient for the entire analysed month.

The results by day and total consumption are presented in table form for all analysed months (OctoberMarch).

Figure 4 present part of the calculation for $24 \mathrm{~h}$ time interval through the days during month January for system architecture - option 1 . 


\begin{tabular}{|c|c|c|c|c|c|c|c|c|c|c|c|c|c|c|}
\hline \multirow[b]{2}{*}{$\begin{array}{l}\text { Day in } \\
\text { month }\end{array}$} & \multirow[b]{2}{*}{$\begin{array}{c}\text { Time } \\
\text { interval } \\
\text { during the } \\
\text { day }\end{array}$} & \multicolumn{11}{|c|}{ System architecture option 1 - with cooling towers in free cooling mode } & \multirow[b]{2}{*}{$\begin{array}{l}\text { Total price for } \\
\text { consumed } \\
\text { cooling water } \\
\mathrm{C}_{\mathrm{rv}, \mathrm{uk} 1} \text { [HRK] }\end{array}$} & \multirow[b]{2}{*}{$\begin{array}{l}\text { Total price of } \\
\text { consumed } \\
\text { electrical } \\
\text { energy } C_{e, l u k 1} \\
\text { [HRK] }\end{array}$} \\
\hline & & $\begin{array}{c}\text { Average } \\
\text { ambient } \\
\text { temperature } \\
\mathrm{T}_{\mathrm{v}, \mathrm{sr}}\left[{ }^{\circ} \mathrm{C}\right]\end{array}$ & $\begin{array}{c}\text { Cooling } \\
\text { capacity [kW] }\end{array}$ & $\begin{array}{c}\text { Total electrical } \\
\text { power absorbed } \\
\text { for cooling } \\
\text { towers } \mathrm{N}_{\mathrm{T}_{1}}[\mathrm{kWW}\end{array}$ & $\begin{array}{l}\text { Total losses of } \\
\text { cooling water on } \\
\text { cooling towers } \\
\Delta \mathrm{V}_{\mathrm{vk1}}\left[\mathrm{m}^{3} / \mathrm{h}\right]\end{array}$ & $\begin{array}{c}\text { Total electrical } \\
\text { power absorbed } \\
\text { for condensator } \\
\text { circulation pumps } \\
\mathrm{N}_{\mathrm{pk} 1}[\mathrm{~kW}]\end{array}$ & $\begin{array}{c}\text { Total electrical } \\
\text { power absorbed } \\
\text { for evaporator } \\
\text { circulation pumps } \\
\mathbf{N}_{\text {pin }}[\mathrm{kW}]\end{array}$ & $\begin{array}{c}\text { Time period } \\
\text { od plant } \\
\text { operation } \\
\text { t[h] }\end{array}$ & $\begin{array}{c}\text { Consumption } \\
\text { of cooling } \\
\text { water } V_{\text {rv1 } 1} \\
{\left[\mathrm{~m}^{3}\right]}\end{array}$ & $\begin{array}{c}\text { Consumption } \\
\text { of electrical } \\
\text { energy } E_{\text {el1 }} \\
{[\mathrm{kWh}]}\end{array}$ & $\begin{array}{l}\text { Unit price for } \\
\text { consumed } \\
\text { cooling water } \\
\mathrm{C}_{\mathrm{nv1}}\left[\mathrm{HRK} / \mathrm{m}^{3}\right]\end{array}$ & $\begin{array}{l}\text { Unit price for } \\
\text { consumed } \\
\text { electrical } \\
\text { energy } \mathrm{C}_{\text {en1 }} \\
\text { [HRKKkWh] }\end{array}$ & & \\
\hline & $0-3 \mathrm{~h}$ & $-8,312$ & 4111,30 & 46,90 & 4,75 & 97,09 & 96,56 & 3,00 & 14,25 & 721,65 & 15,00 & 0,53 & 213,75 & 382,47 \\
\hline & $3-6 \mathrm{~h}$ & $-5,108$ & 3629,96 & 46,90 & 4,90 & 97,09 & 82,63 & 3,00 & 14,70 & 679,86 & 15,00 & 0,53 & 220,50 & 360,33 \\
\hline & $6-9 \mathrm{~h}$ & $-3,652$ & 3474,62 & 46,90 & 4,94 & 97,09 & 79,73 & 3,00 & 14,82 & 671,16 & 15,00 & 0,53 & 222,30 & 355,71 \\
\hline & $9-12 h$ & $-1,639$ & 3174,62 & 46,90 & 5,05 & 97,09 & 74,36 & 3,00 & 15,15 & 655,05 & 15,00 & 0,53 & 227,25 & 347,18 \\
\hline & $12-15 \mathrm{~h}$ & $-0,171$ & 2781,29 & 46,90 & 5,21 & 97,09 & 67,65 & 3,00 & 15,63 & 634,92 & 15,00 & 0,53 & 234,45 & 336,51 \\
\hline & $15-18 n$ & $-0,852$ & $2 y / 1, y 5$ & 46,90 & 0,10 & yi,uy & 10,96 & 3,00 & 15,30 & 644,85 & 15,00 & 0,53 & 229,50 & $341, / I$ \\
\hline & $18-21 \mathrm{~h}$ & $-1,921$ & 3174,62 & 46,90 & 5,05 & 97,09 & 74,36 & 3,00 & 15,15 & 655,05 & 15,00 & 0,53 & 227,25 & 347,18 \\
\hline & $21-24 \mathrm{~h}$ & $-2,771$ & 3277,96 & 46,90 & 4,98 & 97,09 & 76,18 & 3,00 & 14,94 & 660,51 & 15,00 & 0,53 & 224,10 & 350,07 \\
\hline & Total & & 3325,29 & 46,90 & & 97,09 & 77,80 & & 119,94 & 5323,05 & & & 1799,10 & 2821,22 \\
\hline & $20-3 \mathrm{~h}$ & $-3,202$ & 3277,96 & 46,90 & 4,98 & 97,09 & 76,18 & 3,00 & 14,94 & 660,51 & 15,00 & 0,53 & 224,10 & 350,07 \\
\hline & $3-6 \mathrm{~h}$ & $-3,203$ & 3277,96 & 46,90 & 4,98 & 97,09 & 76,18 & 3,00 & 14,94 & 660,51 & 15,00 & 0,53 & 224,10 & 350,07 \\
\hline & $6-9 h$ & $-2,603$ & 3277,96 & 46,90 & 4,98 & 97,09 & 76,18 & 3,00 & 14,94 & 660,51 & 15,00 & 0,53 & 224,10 & 350,07 \\
\hline & $9-12 \mathrm{~h}$ & 0,617 & 2687,95 & 46,90 & 5,17 & 97,09 & 66,11 & 3,00 & 15,51 & 630,30 & 15,00 & 0,53 & 232,65 & 334,06 \\
\hline & $12-15 \mathrm{~h}$ & 1,007 & 2687,95 & 46,90 & 5,17 & 97,09 & 66,11 & 3,00 & 15,51 & 630,30 & 15,00 & 0,53 & 232,65 & 334,06 \\
\hline & $15-18 \mathrm{~h}$ & 0,777 & 2687,95 & 46,90 & 5,17 & 97,09 & 66,11 & 3,00 & 15,51 & 630,30 & 15,00 & 0,53 & 232,65 & 334,06 \\
\hline & $18-21 \mathrm{~h}$ & $-0,064$ & 2781,29 & 46,90 & 5,21 & 97,09 & 67,65 & 3,00 & 15,63 & 634,92 & 15,00 & 0,53 & 234,45 & 336,51 \\
\hline & $21-24 h$ & $-0,517$ & 2977,95 & 46,90 & 5,10 & 97,09 & 70,95 & 3,00 & $\begin{array}{l}15,30 \\
150\end{array}$ & $\begin{array}{l}644,82 \\
62\end{array}$ & 15,00 & 0,53 & 229,50 & 341,75 \\
\hline & Total & & 2957,12 & 46,90 & & 97,09 & 70,68 & & $\begin{array}{l}122,28 \\
\end{array}$ & 5152,17 & & & 1834,20 & 2730,65 \\
\hline
\end{tabular}

Figure 4. Example of calculation for time interval through the days (month January) for system architecture - option 1

\subsubsection{System architecture - option 2 -operation with dry coolers in the free cooling mode}

For this option, we only calculated the electricity consumption $\mathrm{E}_{\mathrm{el} 2}[\mathrm{kWh}]$ (according to the mean outside temperature value for a particular time interval during a day in the analysed month). We used the following data:

- Total electric power transmitted to the dry coolers $\mathrm{N}_{\mathrm{T} 2}[\mathrm{~kW}]$ - provided by the equipment manufacturer;

- Total electric power transmitted to the condenser circulation pumps $\mathrm{N}_{\mathrm{pi} 2}[\mathrm{~kW}]$ - provided by the equipment manufacturer; and

- Total electric power transmitted to the water cooled chiller designed for re-cooling cooled water $\mathrm{N}_{\mathrm{rv} 2}[\mathrm{~kW}]$ - provided also by the equipment manufacturer.

We also calculated the average coefficient EER $_{\text {post2 }}$ for all days, as well as the average value of such coefficient for the entire analysed month.

Figure 5 present part of the calculation for $24 \mathrm{~h}$ time interval through the days during month January for system architecture - option 2.

\begin{tabular}{|c|c|c|c|c|c|c|c|c|c|c|c|c|}
\hline \multirow[b]{2}{*}{$\begin{array}{l}\text { Day in } \\
\text { month }\end{array}$} & \multirow[b]{2}{*}{$\begin{array}{c}\text { Time } \\
\text { interval } \\
\text { during the } \\
\text { day }\end{array}$} & \multicolumn{9}{|c|}{ System architecture 2 - with dry coolers in free cooling mode } & \multirow[b]{2}{*}{$\begin{array}{l}\text { Unit price for } \\
\text { absorbed } \\
\text { electrical } \\
\text { energy } C_{\mathrm{el}} \\
\text { [HRK/kWh] }\end{array}$} & \multirow[b]{2}{*}{$\begin{array}{l}\text { Total price for } \\
\text { absorbed } \\
\text { electrical } \\
\text { energy } \mathrm{C}_{\text {el,uk2 }} \\
\text { [HRK] }\end{array}$} \\
\hline & & $\begin{array}{c}\text { Average } \\
\text { ambient } \\
\text { temperature } \\
\mathrm{T}_{\mathrm{v}, \mathrm{s} r}\left[{ }^{\circ} \mathrm{C}\right]\end{array}$ & $\begin{array}{l}\text { Cooling } \\
\text { capacity } \\
\text { [kW] }\end{array}$ & $\begin{array}{l}\text { Cooling } \\
\text { capacity for re- } \\
\text { cooling of } \\
\text { cooled water } \\
\text { [kW] }\end{array}$ & $\begin{array}{l}\text { Total cooling } \\
\text { capacity [kW] }\end{array}$ & $\begin{array}{c}\text { Total electrical } \\
\text { power absorbed } \\
\text { for dry coolers } \\
\mathrm{N}_{\mathrm{T} 2}[\mathrm{~kW}]\end{array}$ & $\begin{array}{c}\text { Total electrical } \\
\text { power absorbed } \\
\text { for evaporator } \\
\text { circulation pumps } \\
\mathrm{N}_{\mathrm{pi2} 2}[\mathrm{~kW}]\end{array}$ & $\begin{array}{l}\text { Total electrical } \\
\text { power absorbed } \\
\text { for chiller for re- } \\
\text { cooling of cooled } \\
\text { water } \mathrm{N}_{\mathrm{rv} 2}[\mathrm{~kW}]\end{array}$ & $\begin{array}{c}\text { Time period } \\
\text { od plant } \\
\text { operation } \\
t[h]\end{array}$ & $\begin{array}{c}\text { Absorbed } \\
\text { electrical } \\
\text { energy } E_{\mathrm{el} 2} \\
{[\mathrm{kWh}]}\end{array}$ & & \\
\hline & $10-3 \mathrm{~h}$ & $-8,312$ & 4132,72 & & 4132,72 & 27,80 & 93,80 & & 3,00 & 121,60 & 0,53 & 64,45 \\
\hline & $3-6 \mathrm{~h}$ & $-5,108$ & 3476,75 & & 3476,75 & 27,80 & 80,80 & & 3,00 & 108,60 & 0,53 & 57,56 \\
\hline & $6-9 h$ & $-3,652$ & 3222,74 & & 3222,74 & 27,80 & 76,20 & & 3,00 & 104,00 & 0,53 & 55,12 \\
\hline & $9-12 \mathrm{~h}$ & $-1,639$ & 2778,92 & & 2778,92 & 27,80 & 68,52 & & 3,00 & 96,32 & 0,53 & 51,05 \\
\hline & $12-15 \mathrm{~h}$ & $-0,171$ & 2360,22 & & 2360,22 & 27,80 & 52,80 & & 3,00 & 80,60 & 0,53 & 42,72 \\
\hline & $15-18 h$ & $-0,852$ & 2615,63 & & 2615,63 & 27,80 & 65,80 & & 3,00 & 93,60 & 0,53 & 49,61 \\
\hline & $18-21 \mathrm{~h}$ & $-1,921$ & 2778,92 & & 2778,92 & 27,80 & 68,52 & & 3,00 & 96,32 & 0,53 & 51,05 \\
\hline & $21-24 \mathrm{~h}$ & $-2,771$ & 2988,27 & & 2988,27 & 27,80 & 72,10 & & 3,00 & 99,90 & 0,53 & 52,95 \\
\hline & Average & & & \#DIV/0! & 3044,27 & 27,80 & 72,32 & 0,00 & Total & 800,94 & & 424,50 \\
\hline & $20-3 \mathrm{~h}$ & $-3,202$ & 2988,27 & & 2988,27 & 27,80 & 72,10 & & 3,00 & 99,90 & 0,53 & 52,95 \\
\hline & $3-6 \mathrm{~h}$ & $-3,203$ & 2989,27 & & 2989,27 & 27,80 & 72,10 & & 3,00 & 99,90 & 0,53 & 52,95 \\
\hline & $6-9 h$ & $-2,603$ & 2990,27 & & 2990,27 & 27,80 & 72,10 & & 3,00 & 99,90 & 0,53 & 52,95 \\
\hline & $9-12 h$ & 0,617 & 2074,11 & & 2074,11 & 27,80 & 47,70 & & 3,00 & 75,50 & 0,53 & 40,02 \\
\hline & $12-15 h$ & 1,007 & 2074,11 & & 2074,11 & 27,80 & 47,70 & & 3,00 & 75,50 & 0,53 & 40,02 \\
\hline & $15-18 \mathrm{~h}$ & 0,777 & 2074,11 & & 2074,11 & 27,80 & 47,70 & & 3,00 & 75,50 & 0,53 & 40,02 \\
\hline & $18-21 \mathrm{~h}$ & $-0,064$ & 2360,22 & & 2360,22 & 27,80 & 52,80 & & 3,00 & 80,60 & 0,53 & 42,72 \\
\hline & $21-24 \mathrm{~h}$ & $-0,517$ & 2615,63 & & 2615,63 & 27,80 & 65,80 & & 3,00 & 93,60 & 0,53 & 49,61 \\
\hline & Average & & & \#DIV/0! & 2520,75 & 27,80 & 59,75 & 0,00 & Total & 700,40 & & 371,21 \\
\hline
\end{tabular}

Figure 5. Example of calculation for time interval through the days (month January) for system architecture - option 2 
The results for existing plant with comparison for both options of total cost of electrical energy, consumed cooling water and energy consumption are presented in Figure 6 for all analysed months (October-March).

\begin{tabular}{|c|c|c|c|c|c|c|c|c|c|c|}
\hline \multicolumn{7}{|c|}{ System architecture option 1 - with cooling towers in free cooling mode } & \multicolumn{4}{|c|}{$\begin{array}{l}\text { System architecture } 2 \text { - with dry coolers } \\
\text { in free cooling mode }\end{array}$} \\
\hline Month & $\begin{array}{c}\text { Consumption } \\
\text { of cooling } \\
\text { water } \mathrm{V}_{\mathrm{rv} 1} \\
{\left[\mathrm{~m}^{3}\right]}\end{array}$ & $\begin{array}{c}\text { Consumption } \\
\text { of electrical } \\
\text { energy } E_{\text {el1 }} \\
{[k W h]}\end{array}$ & $\begin{array}{c}\text { Total cost of } \\
\text { consumed } \\
\text { cooling water } \\
\mathrm{C}_{\mathrm{N}, \mathrm{uk} 1}[\mathrm{HRK}]\end{array}$ & $\begin{array}{c}\text { Total cost of } \\
\text { consumed } \\
\text { eletrical energy } \\
\mathrm{C}_{\text {el,uk1 }}[\mathrm{HRK}]\end{array}$ & $\begin{array}{l}\text { Total cost of } \\
\text { consumed } \\
\text { energy } C_{u k 1} \\
\text { [HRK] }\end{array}$ & $\begin{array}{c}\text { Average } \\
\text { value of } \\
\text { factor } \\
\text { EER }_{\text {post1 }} \text { by } \\
\text { months }\end{array}$ & Month & $\begin{array}{c}\text { Consumptio } \\
n \text { of } \\
\text { electrical } \\
\text { energy } E_{\mathrm{e} \mid 2} \\
\text { [kWh] }\end{array}$ & $\begin{array}{c}\text { Total cost of } \\
\text { consumed } \\
\text { eletrical energy } \\
\mathrm{C}_{\mathrm{el}, \mathrm{uk} 2}[\mathrm{HRK}]\end{array}$ & $\begin{array}{l}\text { Average } \\
\text { value of } \\
\text { factor } \\
\mathrm{EER}_{\text {post } 2} \text { by } \\
\text { months }\end{array}$ \\
\hline January & 1496,91 & 50769,20 & $22.453,65$ & $26.907,67$ & $49.361,32$ & 15,213 & January & 15377,95 & $8.150,31$ & 7,12 \\
\hline February & 1392,87 & 45095,34 & $20.893,05$ & $23.900,53$ & $44.793,58$ & 13,277 & February & 15869,39 & $8.410,78$ & 14,876 \\
\hline March & 1184,64 & 37291,98 & $17.769,60$ & $19.764,75$ & $37.534,35$ & 11,950 & March & 15410,10 & $8.167,35$ & 11,876 \\
\hline October & 481,65 & 14630,40 & $7.224,75$ & $7.754,11$ & $14.978,86$ & 5,529 & October & 7289,10 & $3.863,22$ & 5,582 \\
\hline November & 936,27 & 29481,54 & $14.044,05$ & $15.625,22$ & $29.669,27$ & 10,358 & November & 12474,47 & $6.611,47$ & 10,354 \\
\hline December & 1495,32 & \begin{tabular}{|l|}
49631,37 \\
\end{tabular} & $22.429,80$ & $26.304,63$ & $48.734,43$ & 14,363 & December & 15894,73 & $8.424,21$ & 11,745 \\
\hline Total & 6987,66 & 226899,83 & 104814,90 & $120.256,91$ & $225.071,81$ & & Total & 82315,74 & $43.627,34$ & \\
\hline
\end{tabular}

Figure 6. Comparison of evaluation method's results for existing cooling plant

\subsection{Evaluation method for the existing part of the cooling plant}

Analogously to the above described analysis for the existing cooling plant, we conducted an energy analysis for the new cooling plant.

The results for new cooling plant with comparison for both options of total cost of electrical energy, consumed cooling water and energy consumption are presented in Figure 7 for all analysed months (October-March).

\begin{tabular}{|c|c|c|c|c|c|c|c|c|c|c|}
\hline \multicolumn{7}{|c|}{ System architecture option 1 - with cooling towers in free cooling mode } & \multicolumn{4}{|c|}{$\begin{array}{l}\text { System architecture } 2 \text { - with dry coolers in } \\
\text { free cooling mode }\end{array}$} \\
\hline Month & $\begin{array}{c}\text { Consumption } \\
\text { of cooling } \\
\text { water } \mathrm{V}_{\mathrm{rv} 1} \\
{\left[\mathrm{~m}^{3}\right]}\end{array}$ & $\begin{array}{c}\text { Consumption } \\
\text { of electrical } \\
\text { energy } E_{\text {el1 }} \\
{[\mathrm{kWh}]}\end{array}$ & $\begin{array}{c}\text { Total cost of } \\
\text { consumed } \\
\text { cooling water } \\
\mathrm{C}_{\mathrm{rv}, \mathrm{uk} 1}[\mathrm{HRK}]\end{array}$ & $\begin{array}{c}\text { Total cost of } \\
\text { consumed } \\
\text { eletrical energy } \\
\mathrm{C}_{\text {el,uk1 } 1}[\mathrm{HRK}]\end{array}$ & $\begin{array}{l}\text { Total cost of } \\
\text { consumed } \\
\text { energy } C_{u k 1} \\
\text { [HRK] }\end{array}$ & $\begin{array}{c}\text { Average } \\
\text { value of } \\
\text { factor } \\
\text { EER }_{\text {post1 }} \\
\text { by } \\
\text { months }\end{array}$ & Month & $\begin{array}{c}\text { Consumption } \\
\text { of electrical } \\
\text { energy } E_{\text {el2 }} \\
{[\mathrm{kWh}]}\end{array}$ & $\begin{array}{c}\text { Total cost of } \\
\text { consumed } \\
\text { eletrical } \\
\text { energy } C_{\text {el,uk2 }} \\
\text { [HRK] }\end{array}$ & $\begin{array}{c}\text { Average } \\
\text { value of } \\
\text { factor } \\
\text { EER }_{\text {post } 2} \text { by } \\
\text { months }\end{array}$ \\
\hline January & 3774,15 & 148259,55 & $56.612,25$ & $78.577,56$ & $135.189,81$ & 11,892 & January & 22477,49 & 11913,07 & 13,42 \\
\hline February & 3467,82 & 130153,02 & $52.017,30$ & $68.981,10$ & $120.998,40$ & 10,513 & February & 21809,67 & $11.559,13$ & 11,965 \\
\hline March & 2919,69 & 107509,20 & $43.795,35$ & $56.979,88$ & $100.775,23$ & 9,466 & March & 20448,80 & $10.837,86$ & 9,440 \\
\hline October & 1114,02 & 40140,39 & $16.710,30$ & $21.274,41$ & $37.984,71$ & 4,222 & October & 9433,80 & $4.999,91$ & 4,518 \\
\hline November & 2334,99 & 87038,31 & $35.024,85$ & $46.130,30$ & $81.155,15$ & 8,202 & November & 15954,05 & $8.455,65$ & 8,273 \\
\hline December & 3715,80 & 142105,23 & $55.737,00$ & $75.315,77$ & $131.052,77$ & 11,295 & December & 22798,96 & $12.083,45$ & 9,394 \\
\hline Total & 17326,47 & 655205,70 & $259.897,05$ & $347.259,02$ & $607.156,07$ & & Total & 112922,77 & $59.849,07$ & \\
\hline
\end{tabular}

Figure 7. Comparison of evaluation method's results for new cooling plant

Figure 8 present us a comparison between system architecture 1 and 2 with final results for both, existing and new cooling plant. 


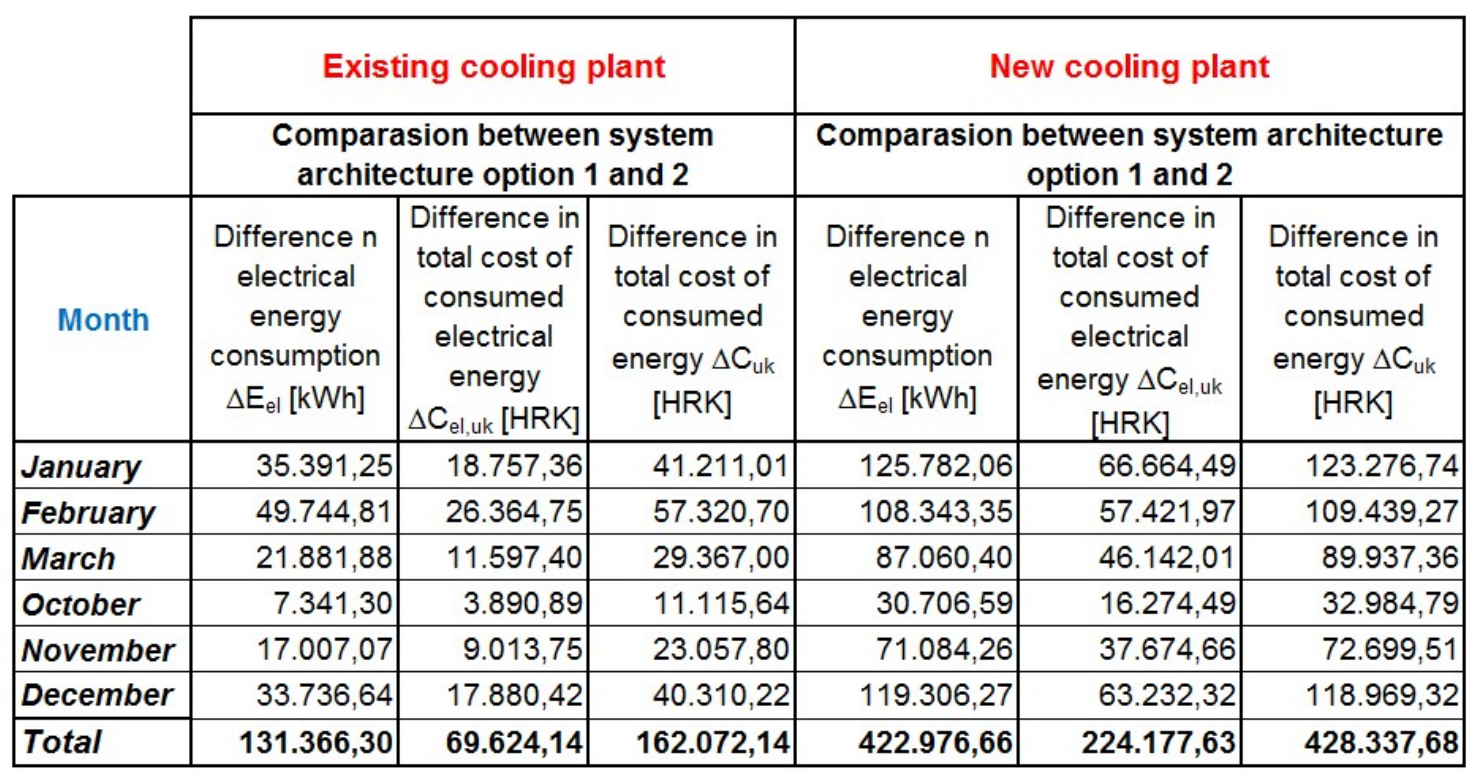

Figure 8. Final results of the evaluation analysis for existing and new cooling plant

\section{Discussion and review of the results obtained}

After verifying the evaluation methods for system architecture 1 and 2 for the existing and new cooling plants, the paper aims to provide a brief discussion of the results obtained. For that purpose, we created a comparative table for the two system architecture for the existing and new cooling plants both for the winter period (months January, February and December) and for the transitional period (months March, October and November) (see Tables No.).

The analysis and its results lead to the following conclusion. System architecture 2, proposed with dry coolers (both to upgrade the existing cooling plant and for the new cooling plant), is definitely costeffective in terms of saving energy.

In short, it can be explained, option 2 of the cooling plant works with dry coolers, and can work even during low outdoor temperatures in the winter period. The system is of closed type, and with the addition of a coolant media such as glycol, it can work at low outside temperatures without risk of system freezing. In the analysis, we assumed that the system would operate in a free cooling regime at outside temperatures below $10{ }^{\circ} \mathrm{C}$. By doing this, the dry cooler fans work with a reduced ratio of electric motors, and no cooling water is needed for supplement in cooling towers. Dry cooler are also connected on evaporator side of the plant, so this machines don't need condenser circulation pumps for their functional work.

The following may be said with respect to the investment: if we observe the total amount to be invested in dry coolers, which is approximately HRK 3,200,000, and compare this amount with the total differences in energy savings (for the existing and new cooling plants), which the analysis found to amount to HRK 590,409.82 (for one year of operation), it may be concluded that the overall investment will have a payback period of 5.42 years in use.

The energy efficiency and reliability of the cooling plant also depend on the software controlling such a complex technical system (eg. example of TRANE's integrated solution Chiller Plant Control (CPC) ( al., 2011). However, the design of the automated control system was not addressed in this paper.

The paper only presents one instance of comparing two system concepts that are often found in cooling systems and in the food and pharmaceutical industries. Of course, the evaluation method may also be used to compare other different concepts, as well as to compare several of them $(3,4$ or more), depending on the presently analysed cooling system problem. In this instance, we focused on comparing concepts that should operate in the winter mode at outside temperatures below $4{ }^{\circ} \mathrm{C}$. 
The authors thought the electricity consumption diagrams comparing the respective energy forms and presenting their costs would not be as clear, understandable and readable as the summary given in these tables. This is why they were not included in this paper.

At the very beginning, the authors set a restriction in the applicability of the method and noted that it only presented an evaluation of cooling concepts and aims to obtain the most energy-efficient system. The trade-off parameters are deemed included in the selected concepts for the respective plant subsystems (such as water coolers, cooling towers, circulation pumps, etc.). As most of the subsystems and components to be incorporated in the system are already known (its architecture has been established), we can say there are quite a number of restrictions and fixed parameters. However, if the method were to be extended to apply to similar systems, these parameters would be changed and different restrictions would be defined. Of course, it all depends on the system itself and its intended purpose. Most decisions concerning the selection of parameters and estimations depend on previously selected (from literature or based on engineering experience) parameters or parameters obtained from such estimations.

\section{Conclusions and directions of possible future research}

The paper presents research in connection with a method of evaluating different cooling plant concepts. This method is of analytical nature and is to be used primarily effectively solve problems regarding the selection of a cooling plant system concept. Irrespective of its complexity, the authors believe the method will be helpful both to inexperienced designers and to designers that have dealt with the matters in question for quite a few years. In future, the method may be applied to some similar problems in practice and may very quickly result in a satisfactory solution for the system. A satisfactory solution refers to a solution with a lower cost of total electricity consumption. If possible, the solution should also satisfy any other requirements specified by the investor.

The greatest strength of the method proposed is in the fact that it can be constantly modified and supplemented with new requirements and restrictions. The method's greatest disadvantage is in the fact that it is designed mostly for these types of plants (HVAC plants) and cannot be applied to other plant types (industrial assembly or manufacturing plants).

The method's verification is presented by comparing two cooling plant concepts. Concept 1 is a cooling plant using cooling towers in the free cooling mode and Concept 2 is a cooling plant using dry coolers in the same mode.

Based on the method proposed, future research should be directed toward implementing software that would use input parameters and proposed similar system and subsystem models to evaluate two cooling plant concepts or more.

\section{References}

ASHRAE Handbook (2011), HVAC Applications, SI ed., Supported by ASHRAE Research, ASHRAE, Atlanta, USA.

Donjerković, P. (1996), Fundamentals and Control of Heating, Ventilation and Air-conditioning systems - part I and II, (in Croatian), Alfa, Zagreb, Croatia.

Duda, S.W. (2012), "Easy-to-use methods for multi-chiller plant energy and cost evaluation", ASHRAE Journal, Vol. 118 No. 1, pp. 325-332.

Energy Design Resources (2009), Chiller Water Plant Design Guide, Energy Design Resources, USA.

Energy Design Resources (2010), Chiller Plant Efficiency - Design Brief, Energy Design Resources, USA.

Hanson, S., Schwedler, M. and Bakkum, B. (2011), Chiller System Design and Control, TRANE Applications Engineering Manual, USA.

Hosnedl, S., Dvorak, J., Srp, Z. and Kopecky, M. (2010), "Design Specification and Evaluation Tool for Design Engineering and Its Management", Proceedings of the $10^{\text {th }}$ International Design Conference DESIGN 2010, Dubrovnik, Croatia, May 17-20, 2010, The Design Society, Glasgow, pp. 799-810.

Justel, D., Vidal, R., Arriaga, E., Vicente Franco V. and Val-Jauregi, E. (2007), "Evaluation Method for Selecting Innovative Product Concepts with Greater Potential Marketing Success", Proceedings of the $16^{\text {th }}$ International Conference of Engineering Design ICED 2007, July 28-31, 2007, Paris, France.

Kroll, E. and Weisbrod, G. (2015), "A Search and Optimization Perspective on Conceptual Design", Proceedings of the 20 $0^{\text {th }}$ International Conference of Engineering Design ICED 2015, Milano, Italy, July 27-31, 2015. 
Osman, K, Pervan, D. and Tomaš, Ž. (2016), "Methodology for Energy Efficient Design of Cooling Plants", Proceedings of the 14th International Design Conference DESIGN 2016, Volume 2: Tools, Practice and Innovation, May 16-19, Dubrovnik, Croatia, The Design Society, Glasgow, pp. 853-864.

Osman, K, Pervan, D. and Tomaš, Ž. (2017), "Configuration and Change Management Approach in Product Variant Design of Chillers", Procedia CIRP 60/ $27^{\text {th }}$ CIRP Design 2017, May 10-12, 2017, Cranfield, UK, pp. 464-469. https://doi.org/10.1016/j.procir.2017.02.032

Recknagel, H., Sprenger, E., Schramek, E.-R. and Čeperković, Z. (2012), "Heating and Air-conditioning 2012", Interklima, 2012, Vrnjačka Banja, Serbia

Saheb, Y., Becirspahic, S., Simon, J. (2006), "Effect of the Certification of Chillers Energy Efficiency", Proceedings of IEECB 2006, Frankfurt, Germany, pp. 4-9.

TRANE (2001), Chilled-Water Systems, TRANE Applications Engineering Manual, USA.

Ullman, D.G. (2010), The Mechanical Design Process, 4th ed., McGraw-Hill Education, New York, USA.

Zapaniotis, A. and Dentsoras, A. (2011), "Redundancy Eliminations and Plausible Assumptions of Design Parameters for Evaluating Design Alternatives", Proceedings of ICED'11 / the 18th International Conference on Engineering Design, Copenhagen, Denmark, August 15-18, 2011.

Dr. Krešimir Osman, Project Manager/ Research Associate Termo Servis Ltd., Sales and technical support department Miramarska 34, 10000 Zagreb, Croatia

Email: kresimir.osman@fsb.hr 